\title{
Principles of Christian Theology in Augustine's Perspective with An Attitude to the Divine Justice
}

\author{
Sajad Zangane-tabar ${ }^{1}$, Ghorban Elmi ${ }^{2} \&$ Jafar Shanazari $^{3}$ \\ ${ }^{1}$ Department of Kalam. Isfahan, (Khorasgan) Branch, Islamic Azad University, Isfahan, Iran \\ ${ }^{2}$ Religions and Mysticism, Tehran University, Tehran, Iran \\ ${ }^{3}$ Islamic philosophy, University of Isfahan, Isfahan, Iran \\ Correspondence: Sajad Zangane-tabar, Department of Kalam. Isfahan, (Khorasgan) Branch, Islamic Azad \\ University, Isfahan, Iran. E-mail: z.sajad@chmail.ir
}

Received: May 6, 2016 Accepted: May 25, 2016 Online Published: June 29, 2016

doi:10.5539/jpl.v9n5p183 URL: http://dx.doi.org/10.5539/jpl.v9n5p183

\begin{abstract}
Faith had a special place in the thought of Augustine, so that it should be considered essential as a starting point in the process of human purification. In this opinion, our knowledge to the seen and believable affairs would be the thoughts and faith respectively. This approch stated about the role of faith in the understanding that revelation invites us to believe and we cannot understand as long as we don't believe. The Greek ideas have been used during Fathers period and its subject matter emphasized that there is a great and infinite God. The concept of God in Greek philosophy was close to the God of the Bible in some ways. Justin martyr confirmed that the Christian faith is the only valid and useful philosophy. More righteous God should be inclusive to the extent of justice's concept. God worship must be a responsibility not just for the chosen nation, but other people also worship him. Augustine and holy texts considered attributes to God such as infinite, substantive, creative, love, goodness, justice, almighty, creator, eternal and penetrating. Augustine knew the God's righteousness attribute eternal and said about God that he is an eternal and immutable truth that is present in our minds and he agreed the formal theory of three hypostases (God, Christ or the Logos and the Holy Spirit). He was one of the greatest Christian theorist of the Trinity; the only real God has been formed from three persons under the names of Father, Son and the Holy Spirit in his view. The most important attribute of God is unity. The doctrine of grace is as the basic Christian concepts. Paul knew the grace implies on the act of mercy of God and also a major factor for salvation. Augustine knew the first humanity's sin great and unjust somehow our minds are unable to understand the damages caused by it. No one are known to be exempted of this just and true punishment unless, free mercy and grace of God release him. Religious reformation motion also questioned the authoritarianism in religious life and its emphasis on the personal aspect of faith that played a role in the transition from the medieval world to the modern era. The impact of Christian classical teachings and the ideas of Augustine was undeniable on the development of Christian theology.
\end{abstract}

Keywords: belief, Christian theology, Augustine, faith

\section{Introduction}

Converting has always been as one of the pillars of the Christian experience from the Jesus' message about repentance and faith until now. Augustine's belief to the Christ was also the base of his religious experience and the new moral perspective.

"I quickly took Paul's book, opened it, and slowly read the part that my eyes saw at first: "not in party and drunkenness and debauchery and strife and jealousy, however, Jesus Christ covered the Lord and did not prepare conditions of fleshly lusts". I did not want to continue reading and I didn't need it further. Immediately after finishing the sentence, something like the light was certainty penetrated in my heart and all the darkness of doubt got away from it" (Wurst, 2014: 186).

Since the beginning of Christianity until the fourth century, Augustine can be considered as the greatest theologian among other theologians and he is known as the greatest and most influential Christian thinker in the history of the church (Thomas, 1998: 133). He was the father of West Church; his thinking surrounded a medieval thinking and had positive and negative deep effects on medieval. Church reformation motion and 
counter-reformation motion in the Catholic Church, both were formed deeply affected by the rediscovery of Augustine's ideas in the sixteenth century. The author knows the church reformation motion as to rebel of the grace teachings of Augustine against its teaching about the church. Certainly, Augustine's impact on Christian theology and the spiritual life is an undeniable practice (Lin, 2001: 80). In this article, it is intended to examine the theory of Augustine's theology and comparison it with some Christian views.

\section{Faith and Reason in the Thought of Augustine}

Faith has a special place in the thought of Augustine, so that he considers it necessary as a starting point in the process of human purification and he believes that an individual moves forward the love of God with the good faith. Therefore, faith is the basis of all things which a person has in Christ and is the beginning of a pure life. If there is no faith in the beginning, it won't benefit at all. He knows faith proceeding of reason considers understanding as the reward of faith and affirms that faith is the condition of understanding and there would be no understanding without faith. He meets the role of reason as pushing toward faith (Teske, 2003: 1; Gilson, 1999: 18). The interesting thing is that in some cases after the belief in biblical texts, Augustine did some works which was done before the belief; so, he attempted to prove the teachings of the scriptures and justify and infer them rationally by providing reasonable proofs (Geisler, 2005: 253). So, he recommended converts to believe in the scriptures in the first instance. Rational exploring can come after it and in the next rank (Steed, 2001: 188). Perhaps the faith pulls the reason in the thoughts of Augustine. Basis of the philosophy of Augustine seems to be firm on rational evidence of God's existence (Gilson, 2000: 10).

Given the importance of faith in the thought of Augustine, it is necessary to explain the meaning of it. Augustine divided the science into two areas in explaining the meaning of faith. He said: "our knowledge is formed of seen things and believable things"; the knowledge to the seen things is thought and to the believable things is faith." This is one of the meanings of faith that is used in the words of Augustine. Elsewhere, he defined faith as "the act of assuming a thing, accepting the truth of what is said or thought with the confirmation" (about the destiny of saints, 2, 5).

Augustine said in Enchiridon dissertation: "faith points to something that cannot be seen, it is related to things in past, present and future because we believe that Christ has died; this is an event in the past. We believe that he is sitting at the right hand of the Father; this is relevant to the present and we believe that he will come as a judge; it is also about the future" (Enchiridon, 2).

Before accepting the Christianity, Augustine believed that church calls people to faith and belief in things that cannot be proved. He said: "Church wanted to believe in some things even if they were provable" (Confessions, $5,6)$. However, after the adoption of Christianity, he perceived that he has believed many ignored issues and the myriad of events that has not seen. However, these beliefs were beliefs that there was no remedy other than adopting them, because if we did not have such trust, we would achieve absolutely nothing in this world. Moreover, Augustine knew the acceptance of such beliefs irrational essentially. Accordingly, faith and belief were to confirm something without complete rational resolution, something with not enough satisfying evidence to rationalize our confirmation quite (Marcus, 1998: 19). In this regard, faith was different and contradictory from the acknowledgement of logical deduction based on its requirements or validating a descriptive issue or relying on tangible and visible evidence. Faith was confirming a thing by credit and authority of other person, on the basis that the person owns more credibility and authority and it was accepted as the competent authority in that area. In the form of faith, it has no rational clarity and consistency of rulings and statements that are evidence-based or derived from other provisions and statements, but to be faithful to the content of the faith get the mind to the complete and clear insight that only appears in beatific life. What is important is that due to the importance and necessity quoted, Augustine knew the function of faith in the order of beginning the process towards perfection, in other words, it was not the finish line, whereas, the love was the end result. Marcus also said that the function of faith in the Christian philosophy of Augustine was only in the beginning and is so-called as a tool for stepping in the right direction while seeking to understand and perception. Faith was only the first step; the first step that guides the mind to the right direction and gave the mind the reward promised that was the entire perception as the main purpose (Marcus, 1998: 20).

Augustine's view has been changed on the place and role of reason in relation with faith. Based on his personal experience that was a rational seeking of the universe that guided him to Christianity, at the beginning of his entrance to the Christian, he said about the relationship between faith with reason that: the reason should be used before believe to understand some concepts. In other words, the reason makes the man ready to believe it. The purpose of this faith was not rational faith but illuminated faith. After obtaining faith, the reason should be used to help believers understand the faith. The faith defines way and aim for the reason and seeks in some extent that 
the faith defines for it. Augustine stated faith and reason with learning and wisdom in terms of the degree of knowledge that each gives to human. The reason was equal to learning and the faith was wisdom. The learning was the first stage of the rational knowledge. At this stage, the reason seek the world without the faith and gains some knowledge. As natural sciences and mathematics is common between the Christian and non-Christian; in the higher sense, the reason of the one who believes in Christ acquires divine illumination. This phase started with faith and grows with the deepening of faith. This knowledge was special for Christians and the Christian attained divine wisdom with this.

Augustine changed his opinions about the role of reason at the end of his life, especially in his confession and renewing his former ideas. At this stage, he rejected thinking before the belief to the extent that stated the reason does not reveal the truth at all (Ilkhani, 2003: 89). Therefore, in this view, the reason is not a way towards truth and wisdom goes nowhere in this valley, he did not know individual reasoning and sensory knowledge as source of the truth. Gilson said in this regard: "Augustine never forgot that the most secure way toward the truth is not a way that begins from the reason that rational believes leads to the faith; but also on the contrary, it is a way that its origin is the faith and comes from the revelation to the reason" (Gilson, 1992:16).

Thus, Augustine cannot accept the claim of traditional philosophy which said the movement starts always with reason in every field of knowledge. In his view, faith is always necessary prerequisite for correct understanding; the faith is a starting point of any development in understanding the truth. Perception is the reward of faith, so that you may understand if you believe. This religious order that has often repeated on the ninth verse of the seventh chapter in the Book of prophet Isaiah said: "If you do not believe, you won't surely remain constant." Therefore, in his view, the faith is prior to the reason, meaning that if there is no faith, the reason does not have a power to achieve its goal, happiness (Marcus, 1998: 21).

In fact, Augustine explicitly stated about the role of faith in the understanding that revelation invites us to believe and we cannot understand as long as we believe. But he said to those who have abandoned the reason completely extremist in Christianity that: The Gospel doesn't ask us to put away the reason, but promises the truth seekers to find out. The faith that Augustine spoke about is a repulsive matter that is given to human by divinity as kindness, because the man who is fallen and descended deeply won't be able to correct it and return to God, unless God starts this process. In this regard, he said in one of his confessions that: If I could believe, I may be healed, but my patient spirit rejected the only remedy that was faith, because of fearing from the new false teachings to be caught (Confessions, 4, 6).

\section{The Concept of God in the Fathers Period}

The major part of Greek philosophy had been formed based on Platonic and Aristotelian philosophy and its theme was the explicit emphasis on the fact that there was one supreme and infinite God. This oneness was a common point of contact with Greek philosophy for Christian fans and the introduced God belonged to unchangeable existence that didn't change and couldn't contact directly with this variable and changeable world; and he was so impervious because he was not influenced by any emotion and feeling. In addition the early church fathers had to solve this contradiction between the concept of God in Greek philosophy and the concept of God in the Bible.

Because the God of Greek philosophy was impervious, he could not contact with the world directly, therefore an intermediary was needed between him and the world. One of the most common words used for the intermediate in Greek philosophy was the term logo which means both reason and word. For example, the concept of real unique God can be seen with the word that was a mean for his relationship with the world in John's Gospel and this created a point of contact with Greek philosophy for fans of Christianity, although there have been some problems. It can be said that there were two problems in this regard: 1) the word was necessary not because of sin, but because the God would not have relationship with the changing and variable world; 2) the word in the Greek sense was different from the God and had lower dignity which this would deny the divinity (deity) from the word.

In Greek thought, the world had been created by a divine being who had a lower level than God and also with old material; so, it didn't created by sublime God because, Greek thought despised the material world, as Paul the Apostle perceived that the concept of resurrection of body is fundamentally contrary with Greek thought in Athens (Acts of apostles, 17-32).

The human was two-dimensional beings composed of body and soul in Greek thinking. Body belonged to this world that was changing and the spirit was a divine flame that belonged to the realm of unchangeable being and had rational nature, and the spirit was imprisoned in the body and the spirit was immortal and true character of the man was his spirit and real destiny of the immortal spirit was to get rid of the body. The human fate was 
God's likeness that eventually got resembles to the God and this implies that the person seeks to be impervious, i.e. having no sense.

So, the God of Greek philosophy in some ways was close to the God of the Bible but differed in some ways, because their vision of immutable and impervious God was in contrast to the God of the Bible who suffers and became the man. Greek thought spoke about the word that mediates, but this was far from the image of Bible of the Christ, because the Greeks understood that the world was not on rule. However they didn't know the root of the problem in refusal to obey a personal God, but also in the changes of the world.

The early church fathers tried to close Greek thought with biblical concepts, so they removed some elements of Greek thought that was contrary to the Bible and Christianity was seen in the Greek thought, but some elements of Greek thought that had preserved the existence of God was the same concept of God which was still considered to be impervious and the asceticism was also based on the same impervious ideal.

Justin martyr was one of the Greek fathers at the church, and long before Christianity was engaged in studying philosophy. Even after becoming a Christian, he wore robes of philosophers and confirmed that the Christian faith is the only valid philosophy (Brown, 1996: 2). He considered Socrates as a Christian person before Christ. It should be noted that some Christian sects believed in a god or gods differed from with the Jesus's God, the Creator of the universe. Among the sects that were existed in the second century AD and were known as Gnosticism believed in the superior and transcendent God that was quite distinct in this world. He had no role in the creation of the world and the world had been created as a result of inferior deity's action whom they knew one with the God of the Old Testament, and said that there were hierarchy of divine beings between transcendent God and the evil world (Lin, 2011: 7).

Among Alexandrian fathers, Clement and Origen cared classical philosophy even more than Justin martyr. Origen used the Platonic ideas to interpret Christian teachings about God, Christ and salvation (Brown, 1996: 3).

\section{The Concept of God in the Bible}

Words that were used in mainstream thinking about God were formed from the Greek word of Theos or its Latin equivalent as Deus. At one end of the spectrum (whole negative), atheism said there is no God. Agnosticism that literally means I did not know believes in the concept that there were no good reasons to prove the existence of God or deny it. Skepticism is meant to doubt on the existence of God. Nathralism is a theory according to which each of the aspects of human existence, such as ethical or religious life is stated based on human existence as a rational or social animal whose life is consistent with the natural environment. At the other extreme (whole positive), there are other theories including: natural theology means the absent God that moves the universe in the far past and then it was abandoned; or concern a position of the historical term that was stated by natural theologians in England in the eighteenth century that is natural (rational) theology alone is sufficient to explain their creative views. Deism that is often used as a term equivalent to monotheism means belief in the existence of God. Several gods (or polytheism) is a common belief among initiatives and the people of Greece and ancient Rome in the West which in accordance with there are certain multiple gods or some people whose faith is in the form of henotheism believe that there are many gods and they worship one of deities that may be the god of their own tribe or nation. Pantheism has been declared effectively by some poets and believes that God is the same with the nature or with the whole world. Regarding monotheism, there is only one absolute transcendent being which is moral and clear and demands unconditional obedience of man; and this concept was heard at the first time in following words: "Hear O Israel, the Lord, our God is the unit Lord. And be kind with the Lord, your God, with all your soul and with all thy strength" and these expressions show that knowledge of Hebrews from God that can be found in the book of Christianity is substantially monotheistic.

The Old Testament (the Jewish scriptures) and the New Testament (the Christian scriptures) show the emergence of monotheism in a fight with polytheism and henotheism belief. Hebrews' God, Lord of Israel was worshiped at the beginning alongside the exotic gods such as Dagon of Palestinians and Chemouch of Moabites. But the main message of the great prophets in 6,7 and 8 centuries BC was primarily Amos, Hosea, Isaiah.1, Jeremiah and Isaiah.2. However, it was incredible at the beginning that Jehovah was no only God of the Hebrews, but also he was the creator of heaven and earth and the referee in entire history and all peoples. Teachings of the Jewish prophets were that although the God chose the Jewish nation in order to convey the message, but He is not only the God of Jews but also the God of gentile nations as well.

A great scholar Bible said: monotheism of Jews was from the intuitive understanding that that God who is more just and righteous should be inclusive as much as the concept of justice. Worship of God must be a responsibility that is not only for the chosen nation, but also other servants of every race and tribe should worship him. John Hick goes on to state that the teachings of prophets demonstrate that the power and dominion of God over human 
life resulted in an inevitable corollary that there is no distance between material and spiritual, religious and non-religious areas, but also a person's existence finds meaning in relation to God in its totality.

\section{The Concept of God's Attributes}

In some Jewish religious books have been written later and perhaps has not been accepted in the public such as the Wisdom of Solomon that was published between the years 50 -100 BC. Sophia spiritual nature and his demiurge attribute is very similar to Maya concept in Indian philosophy. This description expressed "wisdom is a spirit that blows to hang loves (the first chapter, 6), it is human's friends (the seventh chapter, 23), creates all things (the seventh chapter, 21), is able to do and control the whole thing (the seventh chapter, 22), it is the breath of God's power and grace, it is clear and is emanates from the glory of God (the seventh chapter, 25), it's the reflection of immortal light in the clear mirror of God's power (the seventh chapter, 26), and penetrates everything (the seventh Chapter, 22-24), Who is more creator among all the creatures of the universe than the wisdom (the eighth chapter, 6), he is sent as the divine Holy Spirit from heaven (the ninth chapter, 10- 17), and show human the way to recover the right. So here, Sophia was God's companion and had attributes of God such as omnipotent, observer, and creator, and lover, producer, eternal and penetrating in everything. Then he insisted on the expression of God's attribute of justice and stated that justice is eternal. But atheist people cause to death by their words and deeds and sinful and atheist people execute justice with their power because the poor thing is worthless. As said in the older entries, actors of the divine drama included of God in the one hand and his nation on the other hand, the nation was candidate of God, and the God embodied the power of man and nation as the woman, God like any jealous man was extremely careful of female fidelity. The fact that Job's loyalty was subject to a brutal experiment is an example of the kind of jealousy and the thing mentioned in the Book of Job is that why the Lord gave Job to the Devil to be tested and examined and expose to many calamity and disasters; perhaps in the case of Job, the Lord had doubts and wanted to try him (Jung, 2012: 67).

\section{God and the Attributes of God in the Thought of Augustine}

After explaining the concept of God and His attributes in Christianity, now we express the concept of God in the viewpoint of Augustine. Augustine has considered the God as present within our being and beyond our minds and sublime from us and yet dominant on us that there is nothing known better than him (Maor, 1990: 134). He is an eternal and immutable truth that is present in our minds (Augustine, 2001: 100). Hence in accordance with the ideas of Augustine, God is knowable to us directly as passing that is visible to our eyes immediately, and therefore, the God is more esoteric and more natural that our spirit to us (Gilson, 2005: 156).

His argument about God is a proof that is provided by conscience and thought and its starting point is to understand the essential and constant facts by the reason and this is not specific and unique for a certain person, but also all are equally present (de lib.arbit., 2,12,33).

Augustine would not provide one proof for God's existence, but also proved the material world, however, by some points and concise words through the external world. As well, his interpretation of the Bible has an explanation that said:

"Regulation, order, beauty, movement and change of the world and all visible objects declares with no verbal language that they can only be created by a God who is indescribable and intangible big and beautiful".

Or in Book of Genesis (De Gen adlitt., 4, 22, 22), he has said that the ability of creator and his absolute power and authority and surrounding over every creature are causes of his maintenance and if the power abandons guidance of creatures for a moment, they would be destroyed. And he stated about God that: all agree that God is a being that is superior to all creatures in terms of elation and glory and it is said that St Anselm has said God is a being that it cannot be imagined anything larger than him (Copleston, 2008: 87).

Or as quoted by Professor Gilson; Augustine said about the existence of God that: the soul begins to move towards truth from the step of initial doubt and its rejection by the sentence "I'm wrong, therefore I am" and the result is assurance of spirit of accessibility of the truth. And this truth is not discovered in the sensible world, and then refers to itself considering the fact of fallibility and changeability of him, he would discover the constant truth which is beyond the senses and is not depended to the spirit and would affiliate to the God who is the source of all truth (Ibid, 91).

In the teachings of St. Augustine, a big difference between God and the world is stressed. In his opinion, the God is a being with the attributes of eternal, transcendent, pure goodness, absolute and whole omniscient from all directions. He is the cause of everything, and has created the world from nothing. In addition, he believed that God has pre-determined everything in the beginning and knew from the beginning what will happen to the creatures. For many years, Christian Church's imagination of God was similar to that for Augustine. Although 
some scholars, such as John Scotus Eriugena taught that God is the source of all things, but when told that the issue of God and His creation is the one, he taken away from Augustine and he passed him. The Eriugena believed that God in the world and in fact the world is God, but God was supreme and something more than the world.

Christianity was developed in the first centuries of the Christian era and faced with a difficult problem. The God was imagined as the pure, holy and perfect being. Thus, it was necessary to introduce a being such the logos to attribute the creation of the world to him. Many thinkers knew Christ like as this creature. Before Augustine, Christians believed that Jesus was revelator of God as well as revelator of actual humans. Unlike Pelagius, Augustine stated that human is not free to choose between good or bad, but humans are in the bondage of sin and can be released from this only by the grace of God (Hordern, 1989: 21). In addition to Christ as the mediator of God and the world, Christian thinkers believed in the spirit or another force called "Holy Spirit" having divine origins around the world. As a result, there was a need to provide and develop a theory on the relationship between the three forces with each other and with God. The concept of three hypostases was the result of thinking about this issue. They knew God unique, unit and perfect yet composed of three hypostases including God, Christ or the Logos and the Holy Spirit.

Augustine agreed the formal theory of three hypostases; he believed that God is one that manifests itself in the world with three characters. This position is known as Athanasian position because he was responsible for leading a group that had such an opinion. According to their view, Christ is the origin of salvation and came into existence by the Father that is the God. He has eternal life with his father and is from one essence and Christ has shares with all of the nature of father. In Jesus, the Logos or Christ is embedded in the human body. Athanasius also believed that the Holy Spirit is the third being or hypostasis. Thus, in total, there was this picture that unit divinity emerges in three hypostases that all three are from one origin liveried three characters common nature. These hypostases consist of God, son and Holy Spirit (Frost, 2013:158).

\subsection{About Three Kinds of God}

Augustine said that Scaula, highly educated clergyman, has defined three types of God: one is God who is introduced by poets, another is the God of philosophers and the third god is the God of politicians. He said that the type I God is toy, because poets have invented bad and inadmissible issues about the God; the latter is not suitable for people in countries, because this type includes waste things that are prejudicial to be known by people. What are the things that are prejudicial to disclosure for the public? 1) saying to people that Hercules, Asclepius, Kester and Ploks are not God, because some scholars have said they have been human and have been involved by the fate of mortal people; 2) saying people that countries don't have statue of the true Gods, because the true God has no specific gender nor lifetime nor bodily organs; that cleric did not like people to know the truth.

Scaula said that the cause of rejecting poetic gods is that poets demonstrate the gods very bad and when they say one of them is committed the robbery or other sins; they cannot be even compared with good people. As well, they attributed other stupid sayings and deeds to them like as quarreling of three goddesses with each other about beauty award, and the goddesses got married with human and swallowed Saturn of his children. Any bad thing that is far from the nature of God can be found in these poems. But Augustine accepts true God and believes the judgment and the power of real God has determine all kings and the countries and He is the creator of happiness and bountiful of happiness and he has given ground reigns to the righteous servants and the bad ones; but he doesn't do this deliberated act accidental (Augustine, 2012: 4).

Augustine proved that prosperity is to make all our demands and it is a gift from God not a goddess and so, people should worship only the God that can make them happy and if happiness was a goddess, he was worshiped just because the reason.

\subsection{Attributes of God}

\subsubsection{Infinite, Substantive}

After expressing the concept of God, it is provided a brief speech about the divine attributes although a little. Believe in unity appeared at first in prayers, songs, allegories and teachings of the scriptures and has achieved precise definition philosophically in the long history of Christian thought.

Given that the issues of theology have evolved in Christianity more than Judaism, therefore, the resources of Christian Bibles have been used and one of the fundamental concepts that are emphasized in different positions is that God is infinite and unlimited. This emphasis that God is infinite has made Puul Tillich (German-American theologian and philosopher, 1886-1965) to tell we cannot say God exists, that this limits the existence of God. 
In his opinion, questions about God cannot be fundamentally raised and responded. If we ask a question about the existence of him that would be about something so beyond the nature of existence and the response to it, whether positive or negative, would be implicitly negated (the essence of) God. The proof of God's existence is aggressive as much as atheism, because God is pure existence not a being next to other creatures (**** footnote of page 34 of the book written by John Hick, No.1) because Tillich focused on exclusivity of the word "there is" in the realm of the world of creatures and the finite world. So here is the question of whether there are an infinite Creator or not and he knows wrong to prove or disprove its existence. Thus, he opposed to discussing God's existence and believed that the concept of existence cannot be applied in exactly the same meaning for the Creator and the creation of the world, because he knew God as the existence. According to Christian-Jew theology, true life is for God, he is an unlimited being and his various attributes are different sides to the emergence of the infinite truth; and through these characteristics, it can be noted to what the scholastic philosophers have called Aseity that made him to be substantive.

The concept of substantive consists of two elements: 1) the God is not dependent to any reality outside of himself whether to exist or for his attributes and no more sublime being has created him and cannot remove him, his being has infinite richness and perfection, because he has no condition and is the condition of other living entities; 2) His existence is eternal that means neither begins nor ends. If he had a beginning, it must be a reality of existence that precedes him to create and for ending the existence of God, there should be another reality to end his existence. Each of these assumptions are unacceptable with regard to the independence of pure existence of God. So, eternality of God has a meaning more than a mere concept of being without beginning that St. Anselm (great Christian philosopher and theologian, 1033-1109) has said about it: in fact, you have existed not yesterday, and you exist not today and not tomorrow, you're absolutely out of time because yesterday and today and tomorrow are inside the time. Although nothing comes into existence without your providence, however you're neither in time nor in place, but everything is from you because nothing encompass you but you embraces everything (Hick, 2011: 33).

\subsubsection{Creator of the World}

Another divine attributes is creativity that the God is considered as the infinite and substantive creator of all beings in Christian-Jewish tradition. In this theory, creation have meaning beyond the mere creating new forms (like builder who makes a building), but also the creator means to create by nothing (reatio exnihilio) that means to give an existence to the world when there was only God and this concept entails two inevitable corollaries: 1) the first result is an absolute distinction between Creator and creatures such that the creator cannot be considered as the creature and vice versa; 2) the second result is the idea that the universe is absolutely dependent upon God as the creator and principle and origin of the existence of beings. Then also talk about the creation quoted by Aquinas who stated that he denied the concept of eternal creation, because he believed that the creation itself does not imply on the beginning of time, but Christian revelation granted to the beginning of time, but St. Augustine had a different approach that is the act of creation does not occur at the time, but time is a benefit of creation (Ibid, 38).

\subsubsection{Individuation of God}

The opinions expressed in the Jewish and Christian scriptures that God has a personal identity. In the Old Testament, God speaks in human language (for example, I am the God of thy father, the God of Abraham, Isaac, and the God of Jacob) and the Prophets speak in human language to address him (e.g. O God, hear my cry and comply my prayer now) (Psalms, Psalm 61, verse 1). Although belief in the individuation and being addressed of God in the Christianity-Jewish tradition had a long history, the theory of God's personality is related to relatively recent period. Most of theologians knew God as distinguished $(=$ personal $=$ identified $)$. Not a person but the concept of person induces an image of a greatened human being.

\subsubsection{Devine Love, Absolute Goodness}

In continuing divine attributes, the divine goodness is raised that this attribute is used much in the problem of evil, because the problem of evil affected the absolute goodness of God. In the New Testament, the question of the goodness origin of God, love and mercy are used all in one sense. The most important concept among these three is the divine love. To understand how to treat the "New Testament", it should be distinguished between two types of love in the divine love with the Greek word of "agape and Eros" at first. Eros is a physical love and its motivation is lovely characters of beloved. Lover loves the beloved because it is beautiful and enchanting; the beloved also loves the lover due to his subtlety, intelligence and masculine behavior. But in the New Testament, when speaking about God's love to human, the term agape is used. It was not used in a certain sense that distinguishes the meaning of Eros, until the authors of the "New Testament" gave it the concept of kindness with 
the use of this term. Unlike Eros, agape is a love with poor conditions and broad semantic field. The nature of agape is to value the beloved person. Love is used about God that transcends physical love. The universal love of God toward human beings is a love with the origin of not virtues and merits of them, but the essence of God and makes the God as the final rescuer and safety of individual life. God is our refuge and strengths. Unlimited love of God to man leads to this aspect of the religious experience which God demands absolute obedience to the commandments of God. So, God is "Lord" either the "King" either "Father", this content can be considered as another interpretation from the love of God toward humans wanting realization of the potential goodness within human. There is another thing that is more effective between human beings like as love which calls the best good for us and is not convinced but to the fullest possibilities and out potential genius. Following the discussion of divine goodness in which the God has created human nature in such a way that having the highest degree of moral perfection in relation with God, here it is necessary to note divine "wrath" that is one of the main axioms of religious teachings so that St. Paul, whose writings constituted the authentic texts of the New Testament has not describe the God when is angry or with anger, but has spoken such non-specific about of divine wrath that he pointed out the inevitable reaction of the moral order of the universe that God made to opposite the debauchery and corruption (Ibid, 38).

\subsubsection{The Sacred Issue}

Any attribute of God in the Christian-Jewish tradition is presented as a philosophical abstract concept, but a faithful man knowing that he stands in the presence of the seemingly invisible God knows divine fact as the concept of "the sacred issue" that is aware of different whole and larger than everything like as a reality.

Isaiah has expressed this sense of Might and otherness of God so beautiful. An example of his words is as follows: so similitude the God to whom and what similar can be equal with him? An artisan makes the idol and goldsmith covers it with gold and dangles silver chain for him, the one who does not afford such gifts provides the tree that does not rot and asks a skilled artisan to make an idol that does not move (Isaiah, chapter 40, verses 18 to 25$)$.

He makes princes worthless and counteracts judges of the world, he is not planted and the trunk is not still rooted in the ground that blows just on water and are withered and tornadoes catches them as the wind. So, to who likens me to be equal with him? The Holy says that see your eyes to the 'Elleyyeen as raised, who created it (Isaiah chapter 40 verses 25 and 26).

It also goes on to say: God is great and high and dwells in eternity and his name is sacrosanct (Isaiah, chapter 57 verse 15), that my thoughts are not your thoughts, because as the heaven is high above, my ways is higher that your ways and my thoughts than your thoughts (Ibid, chapter 64, verse 6), to find God as sacred is awareness of his unity, he is hidden secret and pure essence and other creatures against him are nothing purely. In short, the Christian-Jewish attitude of God is concerned that the Gad is as infinite, eternal, uncreated, and individualized reality that is the creator of all beings, and he is appears on the human beings as sacred essence and love becomes evident (Ibid, 46) In the following discussion of God's attributes, it will be stated a quoting from Wainwright, though brief, but not unpleasant. He said that the conventional theists believes that the God has four metaphysical traits as simplicity, immutability, timelessness and impassivit that new theists often know these traits problematic.

Simplicity means each of his attributes is identical with other traits and with his essence and nature. God's immutability is knows as a result of his simplicity. In terms of immutability, God is what is exist and his existence or nature, his surrounding intellectual intuition, and his wise action that brings everything with it, all are necessarily immutable. Augustine believed that immutability of God is the result of his perfection, because something that can be changed, cannot protect itself and the thing that is subject to change can lose the being. So, essence is a thing that not only does not change, but did not undergo any changes in anyway regarding the most accurate mean without concern. Timelessness means that God does not have the time position or time stretches and his impassivity means God created the world and devise it, but God is not passive by anything (Wainwright, 2011: 43).

\section{Trinity}

Augustine was as the greatest Christian theorist on Trinity. In his view, true God is formed of three persons under the titles of father-son-Holy Spirit and in fact, the God is one of these three persons of the Trinity. He introduced unity as the most important attribute of God and stated that the three persons are united in terms of essence to prevent three gods and idolatry. He emphasized that the action of the Trinity should be understood beyond the actions of each of the parties. Accordingly, human is created not only based on the God, but also created as Trinity (McGrath,V2: 2005) 
He knew the three categories of essence, quality and quantity as the absolute categories and while the God is an essence, the quantity (high) and quality (good) are attributed to him at the same time that is when we say that God exists, it means he is great and good. God's attributes are identical with his essence. An example for Trinity is the master and slave and their relationship and if the relationship is removed, nothing of their substance become more or less, but the relationship between them makes the Trinity that permits Trinity in the soul and divided it to the three parts of (), reason and life or thinking, understanding and love.

\section{Doctrine of Grace}

The basic concepts of Christianity are the doctrine of grace. Paul was the first person who gave this doctrine a theological concept (Meara, 1995: 84). He knew the grace as implies on God's act of mercy and major factor of salvation (Smedes, 1982: 549). After him, the church fathers developed this concept and Augustine's contribution in addressing this issue was more significant than others. After Augustine, Catholic perception of grace has been proved and opponents of his views were called heretic. Therefore, understanding the doctrine of grace is tied with the historical aspects so that a few concept can be found in Christianity that its understanding is so much dependent on its historical understanding (Most, 2003:384). At the Church of the West, Augustine is known as a theorist of grace. Of course, it should be noted that his view of grace had the same emphasis that Paul had emphasized on this theological concept. This may be because Augustine and Paul's religious experiences were largely similar to each other. What Augustine stated in his book of confessions about his past brings to mind the words of Paul in the first chapter of Galatians treatise mostly (verses 13 and 14). He specifically explained the story of God's favor to him in the ninth and tenth chapters of the book of confessions thanking God for the abundant donation of faith deeply. After such a fervent faith, Augustine, like Paul, was convinced that only divine grace saves people. Perhaps it could be said that the importance of the writings of St. Augustine was not only the cause of his intellectual power, but also it's because that even the most philosophical of his work is rooted in her emotional and spiritual experience (Ogridy, 1998:183). However, what makes that Augustine considered as the foremost advocate of grace was debates and discussions with some of his contemporaries on the relationship between grace and freedom, and in the course of this discussion, he focused on the expansion of the concept of grace. Important point is that although Augustine insisted on the necessity of grace more than anything, but he accepted human freedom fully and described the relationship between grace and freedom in the treatises of grace and authority (c.f: Nicene and Post-Nicene Fathers, V5, 1886:815).

Augustine emphasized the supernatural conflict between original sin and grace that Paul believed more than anyone else. Augustine once said that the sin of human provoked God's wrath and with every sin that a man does, again revive the Adam's sin in itself. Therefore, personal sins allow divine wrath (Most, 2003:384). He referred to the verse "all sinned in him" (Romans, 12: 5) and by reference of "he" to the Adam, he found out not only Adam's original sin from this verse, but also original sin of every man that originally have since birth, if it is inherited from the ground. Further, because of his personal experience of sexual lust in the period of belief in Manichaeism, he related transmission of original sin associated with sexual practice (Kung, 2008: 106). Therefore in this pint of view, the sin was a requirement of collective and ancestral responsibility as well as personal responsibility. Therefore, he believed the baptism must be performed for each baby. The sin that Paul had introduced as led to the fall of man was locked with the human will in the view of Augustine. Augustine said: it is true that man has free will, but the sin is something that will tend to be bad. Augustine also said: original sin is so large and unjust that our reason is not able to understand the damages resulting from it. He said nobody is exempt from this just and true punishment, unless God's free grace and mercy releases him.

\section{Envoy}

Finally, the attitude of Christians toward God, themselves and the world they live has been changed in permanent and irreversible way by means of a period in thinking history of the West that is known as the Enlightenment period. This also refers to the end of the transition period from the medieval to the modern era. Religious reformation motion also questioned the authoritarianism in religious life and its emphasis on the personal aspect of faith that played a role in the transition from the medieval world to the modern era. Ideas that are not only had negligible impact on Christian thought in the early centuries; rather, it still has a glimmer of regret on the new theories inevitably.

\section{References}

Armstrong, K. (2013). Theology from Abraham until now. Translated by Mohsen Sepehr (7th ed.). Markaz publishing.

Augustine. (2008). Confessions. Translated by Sayeh Meisami. Suhrawardi research center, Tehran. 
Augustine. (2012). The city of God. Translated by Hussein Tofighi. University of Religions and Denominations, Qom, Iran.

Brown, C. (1996). Christian philosophy and faith. Translated by Tah Tavous Mikaelian (1st ed.). Scientific and Cultural Publishing Company, Tehran.

Copleston, F. (2008). The history of philosophy (Vol. 2). Translated by Ebrahim Dadju. Cultural and scientific publication, Tehran.

Durant, W. (1997). The history of philosophy. Translated by Abbas Zaryab (13th ed.). Cultural and scientific publications.

Frost, S. E. (2013). The basic teachings of the great philosophers. Bahjat publishing, Tehran.

Geisler, N. (2005). The philosophy of religion. Translated by Hamid Reza Ayatollahi (1st ed.). Hekmat publishing, Tehran.

Gilson, E. (1999). Reason and revelation in medieval. Translated by Shahram Pazuki (2nd ed.). Garros publishing, Tehran.

Gilson, E. (2000). The spirit of philosophy in medieval. Translated by A. Davoudi (3rd ed.). Scientific and Cultural Publishing Company, Tehran.

Gilson, E. (2005). Thomism, An introduction to the philosophy of St. Thomas Aquinas. Translated by Seyed Ziaoddin Dehshiri (1st ed.). Hekmat publishing, Tehran.

Gilson, E. (2006). The essence in thought of philosophers. Hekmat publishing, Tehran.

Grenz, S., \& Olsen, R. (2011). Christian theology in the twentieth century. Translated by Robert Asariyan and Michelle Aghamalian (1st ed.). Mahi publishing.

Hick, J. (2002). The philosophy of religion. Translated by Behzad Saleki. Al-Huda international publications and artistic-cultural institute, Tehran.

Hordern, W. (1989). Protestant theology. Translated by Tah Tavous Mikaelian (1st ed.). Scientific and Cultural Publishing Company, Tehran.

Ilkhani, M. (2003). History of philosophy in the middle ages and the Renaissance. (1st ed.). Samt publishing, Tehran.

Jung, C. G. (2012). The response to Job. Translated by Fouad Rohani. Jam publishing.

Kung, H. (2008). The great Christian thinkers. Translated by group of translators. Studies and Researches Center in religions and faith, Qom.

Lin, T. (2001). History of Christian thought. Translated by Robert Asariyan. Forouzan Rooz publishing.

Maor, A. (1990). Augustine. Translated by Seyed Ali Haghi. The universe of thought. No. 34, P: 126.

Marcus, A. (1998). Augustine. Translated by Khashayar Deihimi. Kouchak publishing, Tehran.

McGrath, A. (2005). Textbook of Jesus theology. Translated by Behrooz Haddadi. Studies and Researches Center in religions and faith, Qom.

McGrath, A. (n.d.). Textbook of Jesus theology (Vol. 2., 1st ed.). Publishing in University of religions and faith.

Meara, F. O. (1995). Thomas, "Grace". Encyclopedia of Religion, 6, 84.

Most, W. J. (2003). "Grace". Encyclopedia of New Catholic, 6, 380.

Nicene and Post-Nicene Fathers. (1886). Series 1, vol. 5, edited by Philip Schaff, Christian Litreratur Pobliblishing Co, New York.

Ogridy, J. (1998). Christianity and heresy. Translated by Abdolrahim Soleimani Ardestani. Taha publishing, Tehran.

Peterson, M. et al. (2000). Reason and religious beliefs. Translated by Ahmad Naraqi and Ebrahim Soltani. Tarh No publishing, Tehran.

Plantinga, A. (2005). God, authority and evil. Translated by Mohammad Saeedi-mehr. Taha publishing, Qom.

Smedes, L. B. (1982). "Grace". the International Standard Bible Encyclopedia, 2, 547.

Steed, C. (2001). Philosophy in ancient Christianity. Translated by Abdolrahim Soleimani Ardestani (1st ed.). Studies and Researches Center in religions and faith, Qom. 
Teske, R. J. (2003). Augustine, ST, New Catholic Encyclopedia. The Catholic Univercity of UAmerica.vol.1.

Thomas, M. (1998). Christian speech. Translated by Hussein Tofighi (1st ed.). Studies and Researches Center in religions and faith, Qom.

Wainwright, W. J. (2011). The philosophy of religion. Translated by Ali Reza Kermani. Educational and research center of Imam Khomeini.

Wurst, R. E. (2014). Christianity through the literature. Translated by Javad Baghbani and Abbas Rasulzadeh (2nd ed.). Imam Khomeini Educational and Research Institute, Qom.

\section{Copyrights}

Copyright for this article is retained by the author(s), with first publication rights granted to the journal.

This is an open-access article distributed under the terms and conditions of the Creative Commons Attribution license (http://creativecommons.org/licenses/by/3.0/). 